\title{
Hubungan Status Gizi dengan Angka Kejadian Infeksi Saluran Pernapasan Akut (ISPA) pada Balita Usia 1-5 Tahun di Surakarta
}

\author{
Wenny Widyawati ${ }^{1}$, Dwi Hidayah ${ }^{2}$, Ismiranti Andarini ${ }^{2}$ \\ 1. Program Studi Kedokteran Fakultas Kedokteran, Universitas Sebelas Maret \\ 2. Bagian Ilmu Kesehatan Anak, RSUD Dr. Moewardi
}

Korespondensi: widyawatiwenny10@gmail.com

\begin{abstract}
ABSTRAK
Pendahuluan: Infeksi Saluran Pernapasan Akut (ISPA) merupakan salah satu penyebab kematian pada balita. Status gizi dapat mempengaruhi kejadian ISPA. Tujuan penelitian ini adalah untuk mengetahui hubungan antara status gizi buruk, kurang, baik, lebih, dan obesitas dengan angka kejadian ISPA pada balita usia 1-5 Tahun di Surakarta.

Metode: Penelitian observasional analitik dengan desain studi case control dilakukan pada 9 September 2019 sampai 15 Oktober 2019 di RSUD Dr. Moewardi dan puskesmas di Surakarta. Subjek penelitian adalah anak berusia 1-5 tahun dengan diagnosis ISPA dan non ISPA, masing-masing sebanyak 120 sampel. Pemilihan puskesmas dilakukan dengan metode stratified random sampling. Data anak diambil dengan metode consecutive sampling. Penelitian dilakukan dengan mengolah data rekam medis dan melakukan klasifikasi status gizi dengan tabel Z-score WHO. Data kemudian dianalisis menggunakan uji Chi Square dan Odds Ratio (OR).

Hasil: Terdapat hubungan antara status gizi buruk $(\mathrm{OR}=8,63$; CI 95\% = 1,875-39,714), status gizi kurang $(\mathrm{OR}=3,776$; CI 95\% = 1,586-8,988), dan obesitas $(\mathrm{OR}=0,154$; CI $95 \%=0,032-0,736)$ dengan angka kejadian ISPA. Sementara, tidak terdapat hubungan antara status gizi lebih $(\mathrm{p}=0,402)$ dengan angka kejadian ISPA.

Kesimpulan: Terdapat hubungan antara status gizi buruk, kurang, dan obesitas dengan angka kejadian ISPA pada balita di Surakarta. Namun, tidak terdapat hubungan antara status gizi lebih dengan angka kejadian ISPA pada balita di Surakarta.
\end{abstract}

Kata Kunci: Status Gizi, Infeksi Saluran Pernapasan Akut (ISPA), Balita

\begin{abstract}
Introduction: Acute Respiratory Infection (ARI) is one of the causes of death in toddler. Nutritional status can affect the incidence of ARI. The purpose of this study was to determine the relationship between poor nutritional status, malnutrition, good nutritional status, overweight, and obesity with the incidence of ARI in toddler aged 1-5 years old in Surakarta.

Methods: An observational analytic approach with a case-control study design was conducted on 9 September 2019 to 15 October 2019 in RSUD Dr. Moewardi and community health centre in Surakarta. Subjects were children aged 1-5 years old who were diagnosed with ARI and non-ARI, each as many as 120 samples. The community health center was selected by using the stratified random sampling method. Children's data was taken by consecutive sampling method. The study was conducted by processing medical record data and classifying nutritional status with the WHO Z-score table. Data were then analyzed using the Chi Square test and Odds Ratio (OR).
\end{abstract}


Results: There is a relationship between poor nutritional status $(p=0.001 ;$ OR $=8.63$; 95\% $C I=1.875-39.714)$, malnutrition $(p=0.002 ; O R=3.776 ; 95 \% C I=1.586-8,988)$, and obesity $(p=0.019 ; O R=0.154 ; 95 \% C I=0.032-0.736)$ with the incidence of ARI. Meanwhile, there was no relationship between overweight $(p=0.402 ;$ OR $=0.417 ; 95 \%$ $C I=0.097-1.8)$ with the incidence of ARI.

Conclusion: There is a relationship between poor nutritional status, malnutrition, and obesity with the incidence of ARI in toddler in Surakarta, and there is no relationship between overweight with the incidence of ARI in toddler in Surakarta.

\section{Keywords: Nutritional Status, Acute Respiratory Infection (ARI), Toddler}

\section{PENDAHULUAN}

Infeksi Saluran Pernapasan Akut (ISPA) merupakan salah satu masalah kesehatan masyarakat yang penting untuk diperhatikan karena menjadi penyebab kematian pada balita di berbagai negara berkembang termasuk Indonesia. ISPA merupakan infeksi akut yang menyerang salah satu bagian / lebih dari saluran napas. Saluran napas terdiri dari hidung sampai alveoli termasuk adneksanya, yang meliputi sinus, rongga telinga tengah, dan pleura $^{1}$. ISPA diawali dengan gejala demam, batuk, pilek, sakit tenggorokan, suara serak, sakit kepala, sakit telinga, dan anoreksia ${ }^{2}$. Infeksi yang terjadi apabila tidak segera ditangani, menjadi semakin berat, masuk ke jaringan paru dan dapat menyebakan pneumonia. Pneumonia merupakan penyakit infeksi penyebab kematian, terutama pada balita ${ }^{3}$.

Penduduk dengan insidensi ISPA tertinggi berada pada kelompok umur 1-4 tahun $(25,8 \%)$. Terdapat 156 juta episode baru di dunia per tahun dimana 151 juta episode $(96,7 \%)$ terjadi di negara berkembang. Dari semua kasus yang terjadi di masyarakat, 7$13 \%$ merupakan kasus berat dan memerlukan perawatan rumah sakit. ISPA merupakan salah satu penyebab utama kunjungan pasien di puskesmas (40\%-60\%) dan rumah sakit $(15 \%-30 \%)^{1}$.

Infeksi Saluran Pernapasan Akut (ISPA) pada balita dipengaruhi oleh beberapa faktor yaitu gizi kurang, status imunisasi yang tidak lengkap, defisiensi vitamin A, polusi udara di lingkungan tempat tinggal, dan orang tua perokok ${ }^{4}$. Gizi kurang menjadi salah satu faktor penyebab ISPA yang sangat berperan.

Status gizi adalah keadaan tubuh seseorang akibat makanan yang dikonsumsinya setiap hari ${ }^{5}$. Berdasarkan panduan asuhan nutrisi pediatrik IDAI (2011), penentuan status gizi ditentukan berdasarkan berat badan (BB) menurut panjang badan (PB) atau tinggi badan $(\mathrm{TB})(\mathrm{BB} / \mathrm{PB} \text { atau } \mathrm{BB} / \mathrm{TB})^{6}$. Grafik pertumbuhan yang digunakan sebagai acuan adalah grafik WHO 2006 untuk anak kurang dari 5 tahun dan grafik CDC 2000 untuk anak lebih dari 5 tahun. Pada tahun 2018, didapatkan masalah gizi kurang di Indonesia sebesar $17,7 \%$, yang berarti masalah kekurangan gizi pada balita di Indonesia masih menjadi masalah kesehatan masyarakat yang mendekati prevalensi tinggi ${ }^{7}$.

Penyakit infeksi dan keadaan gizi kurang merupakan hubungan timbal balik dan sebab akibat. Penyakit infeksi dapat memperburuk status gizi dan seseorang dengan status gizi yang buruk menjadi lebih rentan terhadap infeksi. Tubuh mempunyai cukup kemampuan untuk mempertahankan diri terhadap penyakit infeksi dalam keadaan gizi yang baik. Jika keadaan gizi semakin buruk maka reaksi kekebalan tubuh akan menurun dan menyebabkan kemampuan tubuh untuk mempertahankan diri terhadap serangan infeksi menjadi turun. Kumankuman yang sebetulnya tidak berbahaya, dapat membawa akibat yang fatal berupa kematian dengan keadaan gizi yang buruk. 
Anak yang mengalami malnutrisi berat memiliki sistem imun yang lemah dan fungsi proteksi mukosa saluran napas yang tidak adekuat, sehingga seringkali menyebabkan terjadinya ISPA ${ }^{8}$. Keberadaan penyakit metabolik seperti obesitas juga dapat meningkatkan sejumlah sel pro inflamasi, menurunkan jumlah sel anti-inflamasi, serta menyebabkan penurunan kontrol terhadap infeksi bakteri ${ }^{9}$.

Penelitian yang dilakukan di Desa Wonosari, Kecamatan Kemiri, Kabupaten Purworejo tahun 2010, dengan jumlah sampel sebanyak 36 orang, mendapatkan hasil bahwa terdapat hubungan yang signifikan antara status gizi kurang / buruk dengan kejadian ISPA $^{10}$. Penelitian serupa lainnya yang dilakukan di Puskesmas Pajang Surakarta tahun 2012, dengan jumlah sampel sebanyak 104 orang, menghasilkan kesimpulan bahwa terdapat hubungan yang signifikan antara status gizi dengan kejadian ISPA, dimana anak dengan gizi kurang berisiko 27,5 kali untuk mengalami ISPA dibanding balita dengan gizi baik ${ }^{11}$. Penelitian ini dilakukan pada populasi yang berbeda yaitu pasien anak usia 1 - 5 tahun di RSUD Dr. Moewardi dan puskesmas di Surakarta. RSUD Dr. Moewardi merupakan rumah sakit tipe A dan menjadi pusat rujukan di Surakarta. Penelitian terdahulu hanya menganalisis hubungan antara status gizi kurang / buruk terhadap kejadian ISPA. Penelitian ini akan mengidentifkasi hubungan antara status gizi buruk, kurang, baik, lebih, dan obesitas terhadap angka kejadian ISPA.

\section{METODE}

Penelitian ini merupakan penelitan observasional analitik dengan metode case control. Penelitian case control digunakan untuk mengetahui pengaruh faktor risiko terhadap terjadinya efek dengan pendekatan retrospektif, dimana dilakukan identifikasi kelompok penyakit kasus dan kelompok penyakit kontrol yang terjadi pada masa lalu ${ }^{12}$.

Penelitian dilakukan pada 9 September 2019 sampai 15 Oktober 2019. Penelitian dilakukan melalui pengambilan data rekam medis pasien anak yang terdiagnosis ISPA dalam 3 tahun terakhir, yaitu data bulan Juli 2016 - Juni 2019. Pengambilan data kasus dilakukan di bagian Instalasi Rekam Medis RSUD Dr. Moewardi dan puskesmas di Surakarta. Pengambilan data kontrol dilakukan di puskesmas di wilayah Surakarta.

Pengambilan sampel menggunakan teknik quota sampling. Sampel penelitian sebanyak 240 pasien terdiri atas 120 pasien ISPA dan 120 pasien sehat. Pengambilan data dilakukan dengan menggunakan rekam medis pasien di Instalasi Rekam Medis RSUD Dr. Moewardi dan puskesmas di Surakarta. Puskesmas yang dijadikan tempat pengambilan data adalah Puskesmas Purwosari, Puskesmas Kratonan, Puskesmas Gajahan, Puskesmas Pucangsawit, dan Puskesmas Gilingan. Pemilihan puskesmas dilakukan dengan metode cluster sampling pada puskesmas yang ada di masing-masing kecamatan di wilayah Surakarta. Data anak diambil dengan metode consecutive sampling. Penelitian ini membutuhkan data berat badan, tinggi badan atau panjang badan, tanggal lahir, tanggal kedatangan, serta diagnosis. Data tersebut selanjutnya dianalisis menggunakan program SPSS 22.0.

Data yang telah diperoleh dalam penelitian dianalisis secara univariat untuk mengetahui karakteristik subjek penelitian. Analisis bivariat kemudian dilakukan dengan menggunakan uji Chi Square untuk mengetahui hubungan antara variabel usia, jenis kelamin, dan status gizi dengan kejadian ISPA. Selanjutnya, untuk mengetahui seberapa besar hubungan digunakan metode ukuran asosiasi dengan Odds Ratio (OR). 


\section{HASIL}

\section{Karakteristik subjek penelitian}

Subjek dalam penelitian ini adalah pasien ISPA dan non ISPA berusia $1-5$ tahun masing-masing sejumlah 120 sampel. Tabel 1 menjelaskan bahwa jumlah subjek penelitian yang paling banyak yaitu berusia 1 tahun sebanyak 65 subjek $(27,1 \%)$ sementara yang paling sedikit yaitu berusia 5 tahun sebanyak 21 subjek $(8,8 \%)$. Proporsi jumlah subjek penelitian laki-laki lebih sedikit daripada perempuan yaitu 113 balita laki-laki $(47,1 \%)$ dan 127 balita perempuan $(52,9 \%)$. Subjek dengan status gizi baik memiliki jumlah paling banyak yaitu 178 subjek (74,2\%), diikuti dengan status gizi kurang sebanyak 29 subjek $(12,1 \%)$, status gizi buruk sebanyak 14 subjek $(5,8 \%)$, obesitas 11 subjek $(4,6 \%)$ dan subjek dengan jumlah paling sedikit adalah balita dengan status gizi lebih sebanyak 8 subjek $(3,3 \%)$.

Tabel 1. Karakteristik subjek penelitian

\begin{tabular}{|c|c|c|c|}
\hline & $\begin{array}{c}\text { Non ISPA } \\
\mathrm{a}(\%)\end{array}$ & $\begin{array}{l}\text { ISPA } \\
\mathrm{a}(\%)\end{array}$ & $\begin{array}{l}\text { Total } \\
\mathrm{n}(\%)\end{array}$ \\
\hline \multicolumn{4}{|l|}{ Status Gizj } \\
\hline Buruk & $2(0,8)$ & $12(5)$ & $14(5,8)$ \\
\hline Kurang & $8(3,3)$ & $21(8,8)$ & $29(12,1)$ \\
\hline Baik & $105(43,8)$ & $73(30,4)$ & $178(74.2)$ \\
\hline Lebih & $3(1,3)$ & $5(2,1)$ & $8(3,3)$ \\
\hline Obesitas & $2(0.8)$ & $9(3,8)$ & $11(4,6)$ \\
\hline \multicolumn{4}{|l|}{ Usia } \\
\hline I tahun & $21(8,8)$ & $44(18,3)$ & $65(27,1)$ \\
\hline 2 tahus & $24(10)$ & $31(12,9)$ & $55(22.9)$ \\
\hline 3 tahus & $27(11,3)$ & $21(8,8)$ & $48(20)$ \\
\hline 4 tahun & $35(14,6)$ & $16(6,7)$ & $51(21.3)$ \\
\hline 5 tahun & $13(5,4)$ & $8(3,3)$ & $21(8,8)$ \\
\hline \multicolumn{4}{|c|}{ Jesis Kelamin } \\
\hline Laki-laki & $60(25)$ & $53(22,1)$ & $113(47,1)$ \\
\hline Pertempuan & $60(25)$ & $67(27,9)$ & $127(52.9)$ \\
\hline
\end{tabular}

\section{Uji Chi Square dan Odds Ratio (OR) antara} Status Gizi dengan ISPA

Data yang diperoleh dari hasil penelitian dapat dianalisis menggunakan uji Chi Square karena memenuhi persyaratan, yaitu didapatkan 0 sel dengan frekuensi harapan <1 dan jika didapatkan sel dengan frekuensi harapan $<5$ tidak lebih dari $20 \%$. Berdasarkan Tabel 2 dan Tabel 3 didapatkan bahwa variabel status gizi buruk dan gizi kurang memiliki nilai $\mathrm{p}<0,05$ sehingga dapat dinyatakan bahwa status gizi buruk dan gizi kurang memiliki hubungan yang signifikan dengan angka kejadian ISPA. Tabel 4 menunjukkan bahwa variabel status gizi lebih memiliki nilai $\mathrm{p}>0,05$ sehingga dapat dinyatakan bahwa status gizi lebih tidak berhubungan dengan angka kejadian ISPA. Berdasarkan Tabel 5 didapatkan bahwa variabel obesitas memiliki nilai $\mathrm{p}<0,05$ sehingga dapat dinyatakan bahwa obesitas memiliki hubungan yang signifikan dengan angka kejadian ISPA.

Tabel 2. Hasil Uji Chi Square antara Status Gizi Buruk dengan ISPA

\begin{tabular}{cccccc}
\hline $\begin{array}{c}\text { Status } \\
\text { Gizi }\end{array}$ & $\begin{array}{c}\text { Non ISPA } \\
\text { n(\%) }\end{array}$ & $\begin{array}{c}\text { ISPA } \\
\mathrm{a}(\%)\end{array}$ & $\begin{array}{c}\text { Total } \\
\mathrm{n}(\%)\end{array}$ & $\mathrm{p}$ & $\begin{array}{c}\text { OR } \\
(95 \% \mathrm{Cl})\end{array}$ \\
\hline Buruk & $2(1)$ & $12(6,3)$ & $14(7,3)$ & 0,001 & 8,63 \\
Baik & $105(54,7)$ & $73(38)$ & $178(92,7)$ & & $(1,875-39,714)$ \\
Total & $107(55,7)$ & $85(44,3)$ & $192(100)$ & & \\
\hline
\end{tabular}

Tabel 3. Hasil Uji Chi Square antara Status Gizi Kurang dengan ISPA

\begin{tabular}{|c|c|c|c|c|c|}
\hline $\begin{array}{c}\text { Status } \\
\text { Gizi }\end{array}$ & $\begin{array}{c}\text { Non ISPA } \\
a(\%)\end{array}$ & $\begin{array}{l}\text { ISPA } \\
\text { n( } \%)\end{array}$ & $\begin{array}{l}\text { Total } \\
\text { ㄷ(\%) }\end{array}$ & p & $\begin{array}{c}\text { OR } \\
(95 \% \mathrm{CI})\end{array}$ \\
\hline Kurang & $8(3,9)$ & $21(10.1)$ & $29(14)$ & 0.002 & 3,776 \\
\hline Baik & $105(50,7)$ & $73(35,3)$ & $178(86)$ & & $(1,586-8,958)$ \\
\hline Total & $113(54,6)$ & $94(45,4)$ & $207(100)$ & & \\
\hline
\end{tabular}

Tabel 4. Hasil Uji Chi Square antara Status Gizi Lebih dengan ISPA

\begin{tabular}{cccccc}
\hline $\begin{array}{c}\text { Status } \\
\text { Gizi }\end{array}$ & $\begin{array}{c}\text { Non ISPA } \\
\mathrm{n}(\%)\end{array}$ & $\begin{array}{c}\text { ISPA } \\
\mathrm{n}(\%)\end{array}$ & $\begin{array}{c}\text { Total } \\
\mathrm{n}(\%)\end{array}$ & $\mathrm{p}$ & $\begin{array}{c}\text { OR } \\
(95 \% \mathrm{Cl})\end{array}$ \\
\hline Lebih & $3(1,6)$ & $5(2,7)$ & $8(4,3)$ & 0,402 & 0,417 \\
Baik & $105(56,5)$ & $73(39,2)$ & $178(95,7)$ & & $(0,997-1,8)$ \\
Total & $108(58,1)$ & $78(41,9)$ & $186(100)$ & & \\
\hline
\end{tabular}

Tabel 5. Hasil Uji Chi Square antara Obesitas dengan ISPA

\begin{tabular}{lccccc}
\hline $\begin{array}{c}\text { Status } \\
\text { Gizi }\end{array}$ & $\begin{array}{c}\text { Non ISPA } \\
\mathrm{n}(\%)\end{array}$ & $\begin{array}{c}\text { ISPA } \\
\mathrm{n}(\%)\end{array}$ & $\begin{array}{c}\text { Total } \\
\mathrm{n}(\%)\end{array}$ & $\mathrm{P}$ & $\begin{array}{c}\text { OR } \\
(95 \% \mathrm{C})\end{array}$ \\
\hline Obesitas & $2(1,1)$ & $9(4,8)$ & $11(5,8)$ & 0,019 & 0,154 \\
Baik & $105(55,6)$ & $73(38,6)$ & $178(94,2)$ & & $(0,032-0,736)$ \\
Total & $107(56,6)$ & $82(43,4)$ & $189(100)$ & & \\
\hline
\end{tabular}


Uji Odds Ratio (OR) digunakan untuk mengetahui peluang terjadinya impact dibandingkan dengan peluang tidak terjadinya impact. Pada analisis bivariat ini pengujian Odds Ratio menggunakan tabel $2 \times 2$ yaitu peluang terjadinya ISPA dan tidak ISPA pada balita dengan status gizi buruk, kurang, lebih, dan obesitas.

Berdasarkan uji Odds Ratio didapatkan hasil bahwa balita dengan status gizi buruk mempunyai kemungkinan 8,63 kali untuk mengalami ISPA dibandingkan dengan balita yang memiliki status gizi baik ( $\mathrm{OR}=$ 8,63 ; CI 95\% = 1,875-39,714). Balita dengan status gizi kurang mempunyai kemungkinan 3,776 kali untuk mengalami ISPA (OR = 3,776; CI 95\% = 1,586-8,988). Balita dengan status gizi lebih mempunyai kemungkinan 0,417 kali untuk mengalami ISPA (OR = 0,417; CI $95 \%=0,097-1,8)$. Sementara balita dengan obesitas mempunyai kemungkinan 0,154 kali untuk mengalami ISPA $(\mathrm{OR}=0,154 ;$ CI 95\% $=0,032-0,736)$.

\section{Uji Chi Square dan Odds Ratio (OR) antara Usia dengan ISPA}

Tabel 6. Hasil Analisis Chi Square antara Usia dengan ISPA

\begin{tabular}{lcccc}
\hline Status Gizi & $\begin{array}{c}\text { Non ISPA } \\
\mathrm{n}(\%)\end{array}$ & $\begin{array}{c}\text { ISPA } \\
\mathrm{n}(\%)\end{array}$ & $\begin{array}{c}\text { Total } \\
\mathrm{n}(\%)\end{array}$ & $\mathrm{p}$ \\
\hline I tahun & $21(8,8)$ & $44(18,3)$ & $65(27,1)$ & 0,001 \\
2 tahun & $24(10)$ & $31(12,9)$ & $55(22,9)$ & \\
3 tahun & $27(11,3)$ & $21(8,8)$ & $48(20)$ & \\
4 tahun & $35(14,6)$ & $16(6,7)$ & $51(21,3)$ & \\
5 tahun & $13(5,4)$ & $8(3,3)$ & $21(8,8)$ & \\
\hline
\end{tabular}

Variabel usia terdiri atas 5 variabel numerik, yaitu 1, 2, 3, 4, dan 5 tahun. Analisis statistik dengan uji Chi Square pada variabel usia menunjukkan $\mathrm{p}<0,05$ sehingga dapat dinyatakan bahwa usia memiliki hubungan yang signifikan dengan angka kejadian ISPA.

Analisis statistik juga menunjukkan bahwa jumlah penderita ISPA semakin berkurang seiring dengan bertambahnya usia balita.

\section{Uji Chi Square dan Odds Ratio (OR) antara Jenis Kelamin dengan ISPA}

Tabel 7. Hasil Analisis Chi Square antara Jenis Kelamin dengan ISPA

\begin{tabular}{lccccc}
\hline Status Gizi & $\begin{array}{c}\text { Non ISPA } \\
\mathrm{n}(\%)\end{array}$ & $\begin{array}{c}\text { ISPA } \\
\mathrm{n}(\%)\end{array}$ & $\begin{array}{c}\text { Total } \\
\mathrm{n}(\%)\end{array}$ & $\mathrm{P}$ & $\begin{array}{c}\text { OR } \\
(95 \% \mathrm{Cl})\end{array}$ \\
\hline Laki-laki & $60(25)$ & $53(22,1)$ & $113(47,1)$ & 0,438 & $0,79 !$ \\
Perempuin & $60(25)$ & $67(27,9)$ & $127(52,9)$ & & $(0,476-1,314)$ \\
Total & $120(50)$ & $120(50)$ & $240(100)$ & & \\
\hline
\end{tabular}

Analisis statistik dengan uji Chi Square pada variabel jenis kelamin menghasilkan $p>0,05$ sehingga dapat dinyatakan bahwa jenis kelamin tidak memiliki hubungan yang signifikan dengan angka kejadian ISPA.

Pada uji Odds Ratio didapatkan bahwa balita laki-laki 0,791 kali lebih berisiko menderita ISPA daripada balita perempuan $(\mathrm{OR}=0,791 ;$ CI $95 \%=0,476-1,314)$. Namun, nilai Odds Ratio tidak dapat dipercayai karena tidak terdapat hubungan yang signifikan antara jenis kelamin dengan angka kejadian ISPA.

\section{PEMBAHASAN}

\section{Hubungan Status Gizi dengan Angka Kejadian ISPA pada Balita Usia 1-5 Tahun di Surakarta}

Status gizi memiliki hubungan yang signifikan secara statistik dengan angka kejadian ISPA. Status gizi seseorang dapat menjadikannya rentan terhadap infeksi, demikian juga sebaliknya. Dalam keadaan gizi yang baik, tubuh mempunyai cukup kemampuan untuk mempertahankan diri terhadap penyakit infeksi. Jika keadaan gizi semakin buruk maka reaksi kekebalan tubuh akan melemah dan menyebabkan penurunan kemampuan tubuh untuk mempertahankan diri ${ }^{8}$.

Penelitian yang dilakukan oleh Susantie (2010) memperlihatkan adanya hubungan yang signifikan $(\mathrm{p}=0,015)$ antara status gizi dengan kejadian ISPA. Harga C sebesar 0,436 menunjukkan tingkat hubungan 
keeratan sedang. Penelitian ini dilakukan di Kabupaten Purworejo pada tahun 2010 dengan metode cross sectional dengan jumlah sampel sebesar 36 orang. Hasil penelitian menunjukkan bahwa $8,3 \%$ anak dengan ISPA memiliki gizi baik, $19,4 \%$ anak ISPA menderita gizi kurang, dan tidak didapatkan adanya anak ISPA dengan gizi buruk maupun gizi lebih. Penelitian ini menyimpulkan bahwa semakin tinggi status gizi, maka semakin jarang kemungkinan terkena ISPA ${ }^{10}$.

Hasil penelitian serupa lainnya juga pernah dijelaskan oleh Hadiana (2013) bahwa terdapat hubungan yang signifikan $(\mathrm{p}=0,000)$ antara status gizi terhadap terjadinya ISPA pada balita. Penelitian ini dilakukan di Puskesmas Pajang Surakarta pada tahun 2012 dengan metode cross sectional dengan jumlah sampel sebanyak 104 orang. Hal ini menunjukkan bahwa anak yang mengalami gizi kurang berisiko 27,5 kali untuk mengalami ISPA dibandingkan balita dengan status gizi baik $(\mathrm{RP}=27,5 ; 95 \% \mathrm{CI}=8,372$ $90,328)^{11}$.

Penelitian yang dilakukan oleh Jedrychowski (1998) memperlihatkan bahwa anak usia pra remaja (9-12 tahun) dengan status gizi lebih dan obesitas (BMI $\geq 20) 2$ kali lebih berisiko untuk mengalami ISPA dibandingkan dengan anak dengan status gizi kurang dan buruk ( $\mathrm{OR}=2,02$; $\mathrm{CI} 95 \%=$ 1,13-3,59). Penelitian ini dilakukan di Krakow, Polandia dengan metode cross sectional dengan jumlah sampel sebesar 1.129 orang ${ }^{13}$. Penelitian mengenai status gizi lebih tidak banyak dilakukan sehingga ditemukan keterbatasan dalam mencari tinjauan pustaka. Namun, berdasarkan teori, leptin yang merupakan hormon derivat lemak berfungsi untuk regulasi fungsi pernapasan dan respon imun paru. Balita dengan status gizi kurang atau buruk mengalami defisiensi leptin sedangkan balita dengan obesitas mengalami resistensi leptin, sehingga menjadi lebih rentan terhadap infeksi baik oleh virus maupun bakteri ${ }^{14}$. Berdasarkan teori tersebut, peneliti menyimpulkan bahwa terdapatnya kandungan lemak pada anak dengan status gizi lebih juga dapat menjadi faktor protektif dari kejadian ISPA.

Perubahan ekspresi mediator pro inflamasi (makrofag M1 dan sel T CD8+) dan anti inflamasi (makrofag M2 dan sel Treg) ditunjukkan pada kelompok ISPA obesitas, sehingga mediator tersebut berpotensi dalam patogenesis ISPA terkait obesitas ${ }^{9}$.

Penelitian Maccioni mendapatkan hasil bahwa orang dengan obesitas memiliki risiko 1,55 kali lebih besar untuk menderita infeksi saluran pernapasan atas $\left(\right.$ adjusted $\left._{\text {OR }}=1,55 ; 95 \% \mathrm{CI}=1,22-1,96\right)$ dan 2,02 kali lebih besar untuk menderita infeksi saluran pernapasan bawah $($ adjusted $\mathrm{OR}=$ $2,02 ; 95 \% \mathrm{CI}=1,36-3,00)$. Penelitian ini dilakukan dengan desain cross sectional di Jerman dengan jumlah sampel sebanyak 1.455 sampel. Hasil penelitian ini menyimpulkan bahwa terdapat hubungan antara obesitas dengan resiko infeksi saluran pernapasan. Hal ini juga dipengaruhi oleh faktor pencetus lain seperti pola makan dan kurangnya aktivitas fisik $^{15}$.

Menurut Mancuso (2013) berdasarkan penelitian yang ada, didapatkan bahwa orang dengan obesitas mengalami gangguan pertahanan tubuh terhadap infeksi virus pada mencit model influenza. Namun, dampak obesitas terhadap pneumonia pada manusia masih belum begitu jelas. Berdasarkan hasil observasi yang dilakukan, didapatkan bahwa tikus model obesitas resisten terhadap kejadian pneumonia pneumococcal, dimana terjadi interaksi yang kompleks antara persinyalan reseptor leptin dengan fungsi imun. Studi klinis dan hewan lebih lanjut diperlukan untuk mengklarifikasi hubungan antara peningkatan adiposit dengan kerentanan terhadap kejadian pneumonia ${ }^{16}$.

Hasil analisis terhadap 240 subjek pada penelitian ini, menunjukkan bahwa persentase pasien ISPA dengan status gizi baik merupakan persentase tertinggi, yaitu 
$30,4 \%$. Persentase dibawahnya yaitu status gizi kurang $(8,8 \%)$, status gizi buruk $(5 \%)$, dan obesitas $(3,8 \%)$. Sedangkan persentase terkecil adalah subjek dengan status gizi lebih sebesar $2,1 \%$.

Berdasarkan hasil analisis didapatkan bahwa variabel status gizi buruk, status gizi kurang, dan obesitas memiliki hubungan yang signifikan terhadap angka kejadian ISPA. Sementara status gizi lebih tidak berhubungan dengan angka kejadian ISPA. Hal ini sudah sesuai dengan dasar teori yang ada.

Berdasarkan uji Odds Ratio didapatkan bahwa balita dengan status gizi buruk mempunyai kemungkinan 8,63 kali untuk mengalami ISPA dibandingkan dengan balita yang memiliki status gizi baik ( $\mathrm{OR}=$ 8,63; CI 95\% = 1,875-39,714). Balita dengan status gizi kurang mempunyai kemungkinan 3,776 kali untuk mengalami ISPA (OR = 3,776; CI 95\% = 1,586-8,988). Sementara, balita dengan status gizi lebih mempunyai kemungkinan 0,417 kali untuk mengalami ISPA $(\mathrm{OR}=0,417$; CI $95 \%=0,097-1,8)$. Namun, nilai Odds Ratio pada status gizi lebih tidak dapat dipercayai karena tidak terdapat hubungan yang signifikan antara status gizi lebih dengan angka kejadian ISPA. Hal ini sudah sesuai dengan teori yang ada.

Berdasarkan uji Odds Ratio didapatkan bahwa balita dengan obesitas mempunyai kemungkinan 0,154 kali untuk mengalami ISPA dibandingkan dengan balita yang memiliki status gizi baik ( $\mathrm{OR}=0,154$; CI 95\% $=0,032-0,736)$. Hal ini bertentangan dengan teori yang ada. Hal ini mungkin disebabkan karena terdapatnya berbagai variabel perancu lain yang dapat memengaruhi kejadian ISPA, seperti kondisi orang tua, riwayat imunisasi maupun riwayat pemberian asi dari sampel. Namun, hasil penelitian ini didukung oleh Mancuso (2013) yang menyatakan bahwa obesitas menjadi faktor protektif terhadap kejadian pneumonia yang merupakan salah satu jenis ISPA ${ }^{16}$.
Pendapatan, pendidikan dan pengetahuan, serta pekerjaan orang tua dapat mempengaruhi kejadian ISPA pada anak. ISPA lebih banyak terjadi pada keluarga berstatus ekonomi buruk dibandingkan dengan keluarga berstatus ekonomi baik. Pendidikan orang tua juga dapat membuat orang tua menjadi lebih waspada dalam menjaga kesehatan anaknya dan segera memeriksakan anaknya begitu terserang penyakit. Ibu yang bekerja juga dapat berpengaruh terhadap perawatan yang diterima anak ${ }^{17}$. Anak yang memiliki status imunisasi lengkap terlindungi dari berbagai infeksi pernapasan ${ }^{4}$. Pemberian ASI eksklusif juga dapat memengaruhi status gizi anak ke depannya. Tidak adekuatnya pemberian ASI eksklusif dapat menyebabkan sang anak menjadi lebih rentan terhadap terjadinya penyakit infeksi saluran pernapasan ${ }^{18}$.

\section{Hubungan Usia dengan Angka Kejadian ISPA pada Balita Usia 1-5 Tahun di Surakarta}

Hasil penelitian oleh Fibrila (2015) menyatakan adanya hubungan antara usia anak $(\mathrm{p}=0,018 ; \mathrm{OR}=5,320)$ dengan angka kejadian ISPA. Penelitian ini dilakukan dengan desain case control di Lampung dengan jumlah sampel sebanyak 48 sampel. Hasil penelitian ini menyatakan bahwa insidensi ISPA tertinggi terjadi pada bayi di bawah satu tahun dan insidennya menurun seiring dengan bertambahnya umur.

Hasil penelitian ini menunjukkan bahwa usia memiliki hubungan yang signifikan dengan angka kejadian ISPA pada balita $\quad(p=0,001)$. Hasil penelitian menunjukkan bahwa persentase pasien ISPA berusia 1 tahun merupakan persentase tertinggi, yaitu $18,3 \%$. Persentase dibawahnya yaitu usia 2 tahun $(12,9 \%), 3$ tahun $(8,8 \%)$, dan 4 tahun $(6,7 \%)$. Sedangkan persentase terkecil adalah subjek berusia 5 tahun sebesar $3,3 \%$. Hasil ini sesuai dengan teori yang ada. 


\section{Hubungan Jenis Kelamin dengan Angka Kejadian ISPA pada Balita Usia 1-5 Tahun di Surakarta}

Tidak terdapat hubungan yang signifikan antara jenis kelamin dengan angka kejadian ISPA balita $(\mathrm{p}=0,438$; OR $=0,791$ CI $95 \%=0,476-1,314)$. Hasil ini sesuai dengan penelitian yang dilakukan oleh Fibrila (2015) yang menyatakan bahwa tidak terdapat hubungan antara jenis kelamin dengan angka kejadian ISPA ${ }^{19}$. Hasil ini didukung dengan penelitian yang dilakukan oleh Syahidi (2016) yang dilakukan dengan desain cross sectional di Tebet, Jakarta Selatan dengan jumlah sampel sebanyak 104 sampel. Penelitian ini menyatakan bahwa tidak terdapat hubungan yang signifikan antara jenis kelamin dengan kejadian ISPA anak $(\mathrm{P}=1,00)$. Namun, persentase ISPA pada penelitian tersebut lebih tinggi pada anak laki-laki $(58,7 \%)$ dibandingkan dengan anak perempuan $(41,3 \%)^{17}$. Sedangkan, pada penelitian ini persentase ISPA pada balita perempuan $(52,9 \%)$ lebih tinggi daripada balita laki-laki $(47,1 \%)$.

\section{Keterbatasan penelitian}

1. Desain penelitian ini memiliki keterbatasan, yaitu pengambilan data melalui rekam medis sehingga rawan terjadi bias dan bersifat retrospektif.

2. Data yang dianalisis dalam penelitian ini adalah data sekunder sehingga validitas data tidak dapat dikontrol oleh peneliti.

3. Pada penelitian ini terdapat beberapa variabel perancu yang tidak dapat peneliti kendalikan, yaitu tingkat pendapatan, pendidikan, pengetahuan, dan pekerjaan orang tua, riwayat imunisasi, serta riwayat pemberian ASI.

\section{Saran untuk pengembangan penelitian}

1. Perlu dilakukan penelitian desain kohort dalam jumlah populasi yang lebih luas, khususnya mengenai hubungan obesitas dengan kejadian ISPA balita.
2. Perlu dilakukan penelitian lanjutan dengan mengendalikan variabel-variabel perancu sehingga bisa memberikan hasil penelitian yang lebih akurat.

3. Perlu dilakukan penelitian mengenai status gizi di wilayah Posyandu Anyelir 6, Puskesmas Purwosari, Surakarta, karena ditemukan angka prevalensi balita dengan status gizi kurang dan status gizi buruk yang sangat tinggi.

\section{KESIMPULAN}

Terdapat hubungan antara status gizi buruk, status gizi kurang, dan obesitas dengan angka kejadian ISPA pada balita di Surakarta. Sementara, tidak terdapat hubungan antara status gizi lebih dengan angka kejadian ISPA pada balita di Surakarta.

\section{UCAPAN TERIMA KASIH}

Penulis menyampaikan terima kasih kepada semua pihak yang telah terlibat dan membantu dalam penyelesaian penelitian ini, terutama kepada staff instalasi rekam medis RSUD Dr. Moewardi dan staff Puskesmas Purwosari, Puskesmas Kratonan, Puskesmas Gajahan, Puskesmas Pucangsawit, dan Puskesmas Gilingan.

\section{DAFTAR PUSTAKA}

1. Kementerian Kesehatan Republik Indonesia. Pedoman Pengendalian Infeksi Saluran Pernafasan Akut. Jakarta: Departemen Kesehatan Republik Indonesia; 2011.

2. Tregoning JS, Schware J. Respiratory viral infections in infants: causes, clinical symptoms, virology, and immunology. Clin Microbiol Rev 2010; 23:74-98.

3. IDAI. Hitung Napas Anak: Deteksi Awal Sesak Napas pada Anak dengan Pneumonia. [Internet] 2017 [sitasi 15 April 2019]. Tersedia pada: http://www.idai.or.id/artikel/seputarkesehatan-anak/hitung-napas-anak-deteksiawal-sesak-napas-pada-anak-denganpneumonia.

4. Taksande AM, Yeole M. Risk factors of Acute Respiratory Infection (ARI) in under-fives in a rural hospital of Central India. Journal of 
Pediatric and Neonatal Individualized Medicine 2016; 5(1):e050105.

5. Amalia, EL, Dachlan, Harry S, dan Santoso PB. Integrasi sistem pakar dan algoritma genetika untuk mengidentifikasi status gizi pada balita. Jurnal EECCIS 2014; 8(1).

6. IDAI. Asuhan Nutrisi Pediatrik (Pediatric Nutrition Care). Jakarta: UKK Nutrisi dan Penyakit Metabolik IDAI; 2011.

7. Kementerian Kesehatan Republik Indonesia. Buku Saku Pemantauan Status Gizi Tahun 2017. Jakarta: Direktorat Gizi Masyarakat Kemenkes RI; 2018.

8. Puspitawati N, Sulistyarini T. Sanitasi Lingkungan yang Tidak Baik Mempengaruhi Status Gizi Balita. Jurnal STIKES 2013; 6(1).

9. Iwasaki A, Foxman EF, Molony RD. Early local immune defenses in the respiratory tract. Nat Rev Immunol 2017; 17(1):7-20.

10. Susantie NI. Hubungan Status Gizi dengan Kejadian ISPA pada Balita Umur 1-5 Tahun di Desa Wonosari, Kecamatan Kemiri, Kabupaten Purworejo Tahun 2010 [Karya Tulis Ilmiah]. Yogyakarta: STIKES Jenderal Achmad Yani; 2010.

11. Hadiana SYM. Hubungan Status Gizi Terhadap Terjadinya Infeksi Saluran Pernapasan Akut (ISPA) pada Balita di Puskesmas Pajang Surakarta [Karya Tulis Ilmiah]. Surakarta: Fakultas Kedokteran Universitas Muhammadiyah Surakarta; 2013.

12. Sastroasmoro S. Dasar-dasar Metodologi Penelitian Klinis, Edisi ke-4. Jakarta: Sagung Seto; 2011.

13. Jedrychowski W, Maugeri U, Flak E, Mroz E, Bianchi I. Predisposition to acute respiratory infections among overweight preadolescent children: an epidemiologic study in Poland. Public health 1998; 112(3):189-195.

14. Vernooy JHJ, Ubags NDJ, Brusselle GG, et al. Leptin as regulator of pulmonary immune responses: involvement in respiratory diseases. Pulm Pharmacol Ther 2013; 26(4):464-472.

15. Maccioni L, Weber S, Elgizouli $M$, et al. Obesity and risk of respiratory tract infections: results of an infection-diary based cohort study. BMC Public Health 2018; 18:271.

16. Mancuso P. Obesity and respiratory infections: Does excess adiposity weigh down host defense? Pulm Pharmacol Ther 2013; 26(4):412-419.

17. Syahidi MH, Gayatri D, Bantas K. Faktorfaktor yang Mempengaruhi Kejadian Infeksi Saluran Pernapasan Akut (ISPA) pada Anak Berumur 12-59 Bulan di Puskesmas Kelurahan Tebet Barat, Kecamatan Tebet, Jakarta Selatan, Tahun 2013. Jurnal
Epidemiologi Kesehatan Indonesia 2016; 1(1).

18. Victora CG, Bahl R, Barros AJD, et al. Breastfeeding in the 21st century: epidemiology, mechanisms, and lifelong effect. The Lancet Breastfeeding Series Group 2016; 387(10017):475-490.

19. Fibrila F. Hubungan Usia Anak, Jenis Kelamin, dan Berat Badan Lahir Anak dengan Kejadian ISPA. Jurnal Kesehatan Metro Sai Wawai 2015; 8(2). 